\title{
Oceanography
}

CITATION

Murphy, J.L., and C.I. Measures. 2014. Ocean acidification: The role of $\mathrm{CO}_{2}$. Oceanography 27(1):238-246, http://dx.doi.org/10.5670/oceanog.2014.01.

DOI

http://dx.doi.org/10.5670/oceanog.2014.01

COPYRIGHT

This article has been published in Oceanography, Volume 27, Number 1, a quarterly journal of The Oceanography Society. Copyright 2014 by The Oceanography Society. All rights reserved.

USAGE

Permission is granted to copy this article for use in teaching and research. Republication, systematic reproduction, or collective redistribution of any portion of this article by photocopy machine, reposting, or other means is permitted only with the approval of The Oceanography Society. Send all correspondence to: info@tos.org or The Oceanography Society, PO Box 1931, Rockville, MD 20849-1931, USA. 


\section{Ocean Acidification: The Role of $\mathrm{CO}_{2}$}

BY JENNIFER L. MURPHY AND CHRISTOPHER I. MEASURES

\section{PURPOSE OF ACTIVITY}

» Understand how the $\mathrm{pH}$ of water changes with the addition of $\mathrm{CO}_{2}$

» Understand why increasing the amount of $\mathrm{CO}_{2}$ in the atmosphere is decreasing the $\mathrm{pH}$ of the ocean

» Learn how different human activities affect the concentration of $\mathrm{CO}_{2}$ in the atmosphere

" Understand how temperature affects the solubility of $\mathrm{CO}_{2}$ in aqueous solutions

\section{AUDIENCE}

The laboratory activity was designed for college freshmen and sophomores, mostly non-science majors. Depending on the number of calculations included in the laboratory exercise, the activity could be adapted for high school students or more advanced undergraduates or graduate students. An example laboratory worksheet can be found in the online supplemental material.

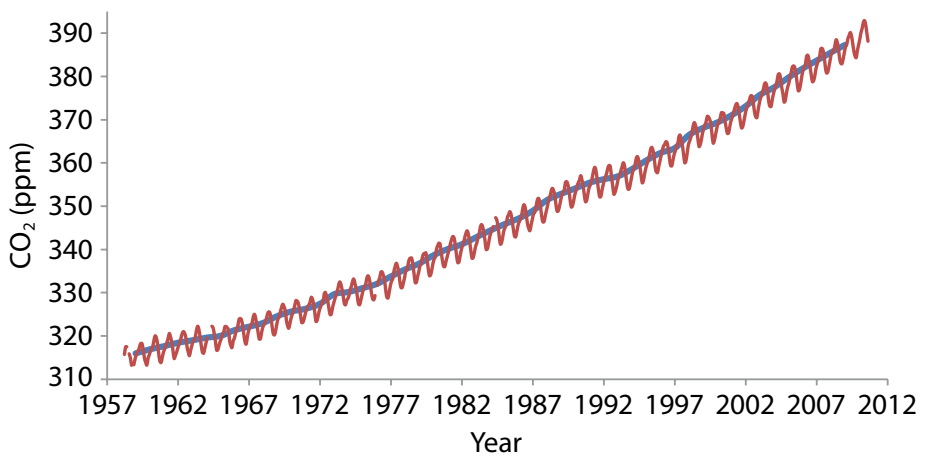

Figure 1. Atmospheric $\mathrm{CO}_{2}$ record from Mauna Loa, Hawai'i. The blue line shows the annual average atmospheric $\mathrm{CO}_{2}$ concentration in ppm. The red line indicates the monthly values, showing the seasonal oscillation in atmospheric $\mathrm{CO}_{2}$ concentration in ppm. From http://www.esrl.noaa.gov/gmd/ccgg/ trends $/$ mlo.html

\section{BACKGROUND}

For the past 250 years, humans have been increasing the amount of carbon dioxide $\left(\mathrm{CO}_{2}\right)$ in the atmosphere through the combustion of fossil fuels and land-use activities. At the beginning of the Industrial Revolution, atmospheric $\mathrm{CO}_{2}$ was 270-280 ppmv (Wigley, 1983; Petit et al., 1999). Over the past 50 years, weekly measurements at Mauna Loa, Hawai'i, have shown an increase in atmospheric $\mathrm{CO}_{2}$ from $317 \mathrm{ppm}$ in 1960 to 390 ppm in 2011 (http://www.esrl.noaa.gov/gmd/ccgg/ trends/mlo.html; Figure 1).

\section{Carbon Reservoirs}

Earth's carbon is stored in several different chemical forms and places called reservoirs (Table 1). It is important to note that the amount of total carbon on the planet has not changed in the past, nor will it change in the future; the carbon merely moves between different reservoirs as a result of geological and geochemical processes and, more recently, anthropogenic

Table 1. Amount of carbon, calculated in $\operatorname{Pg} C\left(P g=\right.$ petagram $\left.=1^{15} \mathrm{~g}\right)$, located in the different reservoirs of Earth's surface (Open University Team, 1989, and Libes, 2009).

\begin{tabular}{|lc|}
\hline Reservoir & Pg Carbon \\
\hline Earth's crust and carbonate sediments & $70,000,000$ \\
\hline Dissolved in the ocean/freshwater & 40,000 \\
\hline Fossil fuels & 7,000 \\
\hline Organic carbon in soils & 2,000 \\
\hline Living biological material & 800 \\
\hline Atmosphere & 800 \\
\hline
\end{tabular}


activities. From Table 1, it is clear that the majority of the carbon on Earth's surface is stored in the carbonate sediment reservoir. Carbonate sediments are composed of the discarded shells and skeletons of animals and plants that have lived in the ocean as well as a limited amount of inorganic carbon precipitated from seawater. While alive, these organisms take up carbon and calcium from the water and, by combining them, build structures of the compound calcium carbonate $\left(\mathrm{CaCO}_{3}\right)$, a process called calcification. (It is important to note that each time an organism produces one mole of $\mathrm{CaCO}_{3}$ for its shell, one mole of $\mathrm{CO}_{2}$ is also produced-exactly how much of that $\mathrm{CO}_{2}$ remains dissolved in the ocean and how much is released into the atmosphere is a function of the temperature of the ocean and the partial pressure of $\mathrm{CO}_{2}$ in the overlying atmosphere.) When $\mathrm{CaCO}_{3}$-producing organisms die, the $\mathrm{CaCO}_{3}$ shells and skeletons slowly sink to the bottom of the ocean. In transit, much of the $\mathrm{CaCO}_{3}$ is dissolved in the water column, but about $35 \%$ of the $\mathrm{CaCO}_{3}$ is buried in sediment and becomes part of the carbonate sediment reservoir. The transfer of carbon from the surface ocean to the deep ocean is referred to as the biological pump, and the rate of carbon transfer between the surface and the deep ocean can change on time scales of human generations. Burial of $\mathrm{CaCO}_{3}$ in ocean sediment is an example of a $\mathrm{CO}_{2}$ sink because carbon is being removed from the ocean and atmosphere reservoirs.

The total amount of carbon stored in the carbonate sediment reservoir changes on very long time scales (thousands to millions of years) related to geological processes, such as plate tectonic activity. Therefore, the carbon stored in the carbonate sediment reservoir is not playing a role in the changes in atmospheric $\mathrm{CO}_{2}$ concentrations that we have observed over the last few hundred years. In addition, the rate at which carbon is transferred out of the carbonate sediment reservoir is relatively slow and constant, unlike the current rise in atmospheric $\mathrm{CO}_{2}$. The recent increase in atmospheric $\mathrm{CO}_{2}$ concentrations has been attributed to human combustion of fossil fuels and land use changes, such as deforestation and desertification. Notice from Table 1 that burning all of the fossil fuels, which releases the carbon from the fossil fuel reservoir directly into the atmospheric reservoir as $\mathrm{CO}_{2}$, could, if no other processes occurred, increase the amount of $\mathrm{CO}_{2}$ in the atmosphere to more than ten times its current value.

When fossil fuels are burned, the carbon from the fossil fuel reservoir is transferred to the atmospheric reservoir immediately. Once in the atmosphere, $\mathrm{CO}_{2}$ partitions between the atmospheric and oceanic reservoirs as a result of air-sea gas exchange that is described by Henry's Law (see theory section for fuller discussion). Essentially, as the amount of $\mathrm{CO}_{2}$ in the atmosphere increases, more $\mathrm{CO}_{2}$ dissolves into the ocean to reach an equilibrium between the atmospheric and oceanic reservoirs. As humans continue to rapidly move carbon from the fossil fuel reservoir into the atmospheric reservoir by burning fossil fuels, we need to understand how the climate and geochemical cycles of the planet are going to be affected.

An increase in the concentration of atmospheric $\mathrm{CO}_{2}$ influences both global temperatures and ocean chemistry. Earth balances the heat it gains from the sun by radiating energy at infrared wavelengths back out to space. Greenhouse gases

\section{WHY DOES AN INCREASE IN ATMOSPHERIC $\mathrm{CO}_{2}$ CHANGE THE $\mathrm{pH}$ OF THE OCEAN?}

absorb some of that infrared radiation, resulting in increased heating of Earth, and it is well established that $\mathrm{CO}_{2}$ is a greenhouse gas, along with methane and water vapor. While comprising only $\sim 0.04 \%$ of the atmosphere, $\mathrm{CO}_{2}$ is very important in regulating Earth's surface temperatures, and as the amount of $\mathrm{CO}_{2}$ in the atmosphere increases, that heating effect will grow larger.

Increased atmospheric $\mathrm{CO}_{2}$ concentrations also affect ocean chemistry because about one-third of the $\mathrm{CO}_{2}$ emitted annually into the atmosphere dissolves into the surface ocean as a result of Henry's Law. All evidence to date indicates that as $\mathrm{CO}_{2}$ concentrations in the atmosphere rise and more $\mathrm{CO}_{2}$ dissolves into the ocean, the ocean will become more acidic and less saturated with respect to $\mathrm{CaCO}_{3}$ (see below), slowing organisms' calcification rates. A reduction in the rate of calcification will decrease the amount of $\mathrm{CO}_{2}$ removed from the surface ocean and transferred to the deep ocean, which will decrease the rate of carbonate sediment production (a sink for $\mathrm{CO}_{2}$ ). Moving carbon from the fossil fuel reservoir to the atmosphere and subsequently to the ocean reservoir will reduce the rate of carbon transfer to the carbonate sediment reservoir.

Jennifer L. Murphy (jlmurphy@hawaii.edu) was a graduate student and Christopher I. Measures is Professor, Department of Oceanography, University of Hawai'i, Honolulu, HI, USA. 


\section{Chemistry}

The $\mathrm{pH}$ of a solution is a measure of the concentration of free hydrogen atoms $\left(\mathrm{H}^{+}\right)$available-the more $\mathrm{H}^{+}$, the more acidic the solution. Solutions are classified as acidic $(\mathrm{pH}<7)$, neutral $(\mathrm{pH}=7)$, or basic $(\mathrm{pH}>7)$ based on the number of free $\mathrm{H}^{+}$ ions present. When $\mathrm{CO}_{2}$ dissolves in the ocean, the molecule can partition into several different forms, some of which alter the $\mathrm{pH}$ of the solution. When dissolved in water, the vast majority (400:1) of $\mathrm{CO}_{2}$ forms $\mathrm{CO}_{2(\mathrm{aq})}$, which has no effect on $\mathrm{pH}$. However, the remaining $\mathrm{CO}_{2}$ molecules react with water to form the diprotic acid $\mathrm{H}_{2} \mathrm{CO}_{3}$ (Equation 1), which then partitions into the various species shown in Equations 2 through 4. Exactly which of these chemical species is dominant depends on the $\mathrm{pH}$ of the solution (Figure 2).

$$
\begin{aligned}
& \mathrm{CO}_{2(\mathrm{~g})} \leftrightarrow \mathrm{CO}_{2(\mathrm{aq})}+\mathrm{H}_{2} \mathrm{O} \leftrightarrow \mathrm{H}_{2} \mathrm{CO}_{3} \\
& \mathrm{H}_{2} \mathrm{CO}_{3} \leftrightarrow \mathrm{HCO}_{3}^{-}+\mathrm{H}^{+} \\
& \mathrm{HCO}_{3}^{-}+\mathrm{H}^{+} \leftrightarrow \mathrm{CO}_{3}^{2-}+2 \mathrm{H}^{+}
\end{aligned}
$$

The average $\mathrm{pH}$ of surface seawater is 8.1 - slightly alkaline. As Figure 2 shows, at a $\mathrm{pH}$ of 8.1 , the presence of $\mathrm{HCO}_{3}^{-}$is favored over the other two chemical species $\left(\mathrm{H}_{2} \mathrm{CO}_{3}\right.$ and $\mathrm{CO}_{3}^{2-}$ ). Therefore, every time a molecule of $\mathrm{H}_{2} \mathrm{CO}_{3}$ forms from the dissolved $\mathrm{CO}_{2}$, it partitions into $\mathrm{HCO}_{3}^{-}$, and one $\mathrm{H}^{+}$molecule is released into the water (Equation 4).

$$
\mathrm{CO}_{2(\mathrm{aq})}+\mathrm{H}_{2} \mathrm{O} \longleftrightarrow \mathrm{HCO}_{3}^{-}+\mathrm{H}+
$$

Thus, the dissolution of $\mathrm{CO}_{2}$ in water causes a decrease in $\mathrm{pH}$ because the quantity of $\mathrm{H}^{+}$in the solution is increased. Additionally, as the $\mathrm{pH}$ of the solution decreases, the amount

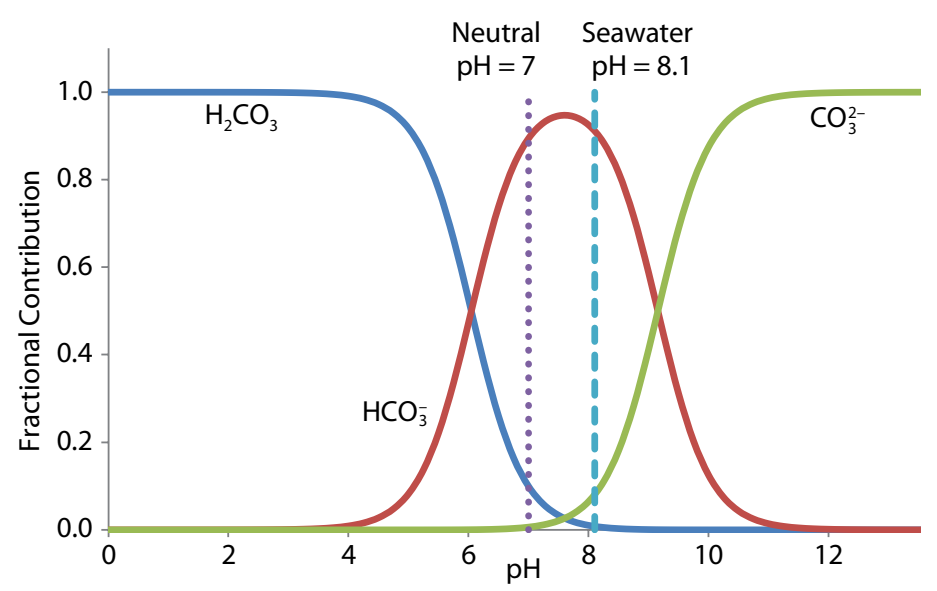

Figure 2. Speciation diagram for $\mathrm{H}_{2} \mathrm{CO}_{3}$ indicating the fractional composition of each of the three chemical species as $\mathrm{pH}$ changes. The dashed lines show neutral $\mathrm{pH}$ and the $\mathrm{pH}$ of seawater. of $\mathrm{CO}_{3}^{2-}$ will also decrease (see Figure 2), reducing the buffering capacity of the water (more on this later). Organisms that use $\mathrm{CaCO}_{3}$ to build shells and skeletons, such as corals, Coccolithophores, and Foraminifera, are especially affected by decreased $\mathrm{pH}$ due to the decrease in the $\mathrm{CaCO}_{3}$ saturation state. The $\mathrm{CaCO}_{3}$ saturation state is the concentration of $\mathrm{Ca}^{2+}$ multiplied by the concentration of $\mathrm{CO}_{3}^{2-}$. As more $\mathrm{CO}_{2}$ dissolves into the ocean, more $\mathrm{H}^{+}$is released, decreasing the $\mathrm{pH}$ of the water, which lowers the fractional contribution of $\mathrm{CO}_{3}^{2-}$ (Figure 2), thus causing a decrease in the $\mathrm{CaCO}_{3}$ saturation state. Therefore, more $\mathrm{CO}_{2}$ dissolved in seawater will make it difficult for some organisms, such as corals, to form $\mathrm{CaCO}_{3}$ structures, reducing the rate of the biological pump and slowing carbonate sediment creation.

As $\mathrm{CO}_{2}$ levels in the atmosphere increase through the combustion of fossil fuels and changes in land use activities, some of that $\mathrm{CO}_{2}$, by processes such as diffusion and turbulent mixing (e.g., ocean waves), transfers from the atmosphere into the surface ocean to reach an equilibrium, as dictated by Henry's Law. The ocean is a complex system and is influenced by a combination of physical, biological, and chemical processes. For example, physical mixing at the water-air interface causes gas exchange between the ocean and atmosphere. Biological respiration decreases ocean $\mathrm{pH}$ by releasing $\mathrm{CO}_{2}$ into the water, forming $\mathrm{CO}_{2(\mathrm{aq})}$, and about 1 part in 400 of this, as discussed above, will transform into $\mathrm{HCO}_{3}^{-}$and $\mathrm{H}^{+}$.

Despite the numerous physical, biological, and chemical processes occurring in the ocean, seawater's $\mathrm{pH}$ remains relatively constant over short time periods due to chemical buffering. Chemical buffering in the ocean occurs because there are a number of dissolved ions capable of taking up $\mathrm{H}^{+}$(including, for example, $\left.\mathrm{HCO}_{3}^{-}, \mathrm{CO}_{3}^{2-}, \mathrm{HSO}_{4}^{-}\right)$. When acids $\left(\mathrm{H}^{+}\right)$are added to the ocean, the reactions such as those in Equations 2 and 3 can move from right to left, lowering the concentration of $\mathrm{H}^{+}$. In the ocean, the buffering capacity, or ability of a solution to absorb $\mathrm{H}^{+}$, is measured by alkalinity, which in simplest terms is a sum of the bases present in the solution. An equivalent process buffers seawater from becoming alkaline when $\mathrm{OH}^{-}$is added. However, buffering capacity is limited and does not prevent all changes in oceanic $\mathrm{pH}$; the buffering capacity reduces the effect. If enough $\mathrm{H}^{+}$(or $\left.\mathrm{OH}^{-}\right)$is added, the buffering capacity of the ocean can be exceeded, which would cause the ocean's $\mathrm{pH}$ to change much more rapidly than at present, decreasing environmental stability, and affecting organisms that depend on relatively constant $\mathrm{pH}$ to survive. 


\section{QUESTIONS FOR LAB ACTIVITY}

» Why does an increase in atmospheric $\mathrm{CO}_{2}$ change the ocean's $\mathrm{pH}$ ?

" Does water temperature influence the quantity of $\mathrm{CO}_{2}$ the water is able to take up?

\section{MATERIALS}

Materials needed for an instructor demonstration and five student groups:

» 12 tire valve stems-screw-in type with gaskets (not the snap-in type). The valve stems (e.g., Gorilla Automotive VS401C Outer Mount Valve Stems) can be found in most auto parts stores.

» 12 plastic $1 \mathrm{~L}$ soda bottles with plastic caps

» $5500 \mathrm{~mL}$ graduated cylinders

» $5 \mathrm{~L}$ hot water $\left(\sim 50^{\circ} \mathrm{C}\right)$

» $5 \mathrm{~L}$ cold water $\left(\sim 10^{\circ} \mathrm{C}\right)$

» 5 tire pressure gauges

" $\mathrm{pH}$ paper or a handheld $\mathrm{pH}$ meter (optional)

» $S$ mall ( $5 \mathrm{lb}$ or $2.27 \mathrm{~kg}$ ) $\mathrm{CO}_{2}$ cylinder with pressure regulator, hose, and tire chuck (the tire chuck can be bought at most hardware stores)

» 1,000 $\mathrm{mL}$ seawater at room temperature (or baking soda dissolved in tap water to act as a buffered solution; see below for details)

" Methyl red $\mathrm{pH}$ indicator dye (C15H15N3O2 in 0.1\% ethanol; VWR catalog number AA38698-AE CAS \# 493-52-7)

» Drill press or a drill (to build the bottle cap assembly before the laboratory)

Note: A modified version of this activity can be completed using a home soda making machine. Though the soda machine setup will not allow the measurement of gas pressure within the bottle, for those instructors who are concerned with gas cylinder safety, using the home soda carbonators may be a better option. Depending on the model, these systems typically pressurize bottle headspace between 30 and 55 psi.

\section{ACTIVITY}

Before the laboratory, build the bottle cap assembly (Figure 3). Drill out the plastic bottle caps and insert the tire valves so that there is a rubber gasket on the top and another on the bottom of the cap. The drill bit should be slightly larger than the valve stem to ensure easy assembly. Use a wrench to tighten the tire valves on the caps to prevent leaking during the activity.

\section{Demonstration}

The $\mathrm{pH}$ indicator methyl red is yellow under roughly neutral or basic conditions ( $\mathrm{pH} \geq 6.2$ ) and red under acidic conditions $(\mathrm{pH}<4)$. (It is orange between these $\mathrm{pH}$ values.) Note: Due to variations in the volume of the bottle used, as well as $\mathrm{pH}$ and buffering capacity of the local water source (water from areas with chalk soils will already have a high buffering capacity), the headspace volume (i.e., the amount of $\mathrm{CO}_{2}$ you need to obtain the desired effect) required for this demonstration will vary. We suggest experimenting with your water supply to determine the actual volume of headspace needed.

\section{Step 1: Prepare/Obtain Water}

If seawater is not available, or to ensure the demonstration works properly, create an artificially buffered solution by dissolving approximately $30 \mathrm{~g}$ ( 2 tablespoons) of sodium bicarbonate $\left(\mathrm{NaHCO}_{3}\right.$; baking soda) per liter of water. The baking soda should completely dissolve in the water, so that no visible trace of the solid remains. Note: Sodium bicarbonate is a buffer for the solution. When dissolved, the dissociation of $\mathrm{NaHCO}_{3}$ into $\mathrm{Na}^{+}$and $\mathrm{HCO}_{3}^{-}$increases the buffering capacity of the water by providing an uptake mechanism for $\mathrm{H}^{+}$, created when $\mathrm{CO}_{2}$ dissolves into the water. The actual amount of baking soda required to buffer the water will vary slightly based on whether deionized/distilled water or tap water is used, as well as the initial alkalinity of the tap water.

\section{Step 2: Freshwater Bottle}

Label the bottle. Then add approximately 1,000 $\mathrm{mL}$ of room temperature water and approximately $1 \mathrm{~mL}$ of methyl red indicator dye.

\section{Step 3: Ocean Bottle}

Label the bottle. Then add approximately $1,000 \mathrm{~mL}$ of room temperature seawater (or artificially buffered water) and approximately $1 \mathrm{~mL}$ of methyl red indicator dye. (Again,

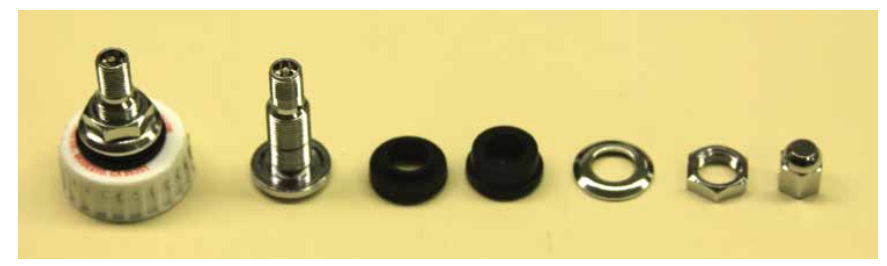

Figure 3. Pieces required for the bottle caps. On the left is a fully assembled bottle cap, with the pieces for the tire-valve step on the right. The bottle cap is inserted between the two black seals. The clamp-in tire valves can be purchased online or at auto parts stores. 
the actual water volume required for a successful demonstration will vary slightly by bottle type, so test the demo before it is run.)

\section{Step 4: $\mathrm{CO}_{2}$ Addition}

Secure the caps (hand tight), and add approximately 30 pounds per square inch (psi) of $\mathrm{CO}_{2}$ to the headspace of each bottle. Note: If the freshwater bottle is not shaken as the $\mathrm{CO}_{2}$ is added, it is possible to observe the diffusion of $\mathrm{CO}_{2}$ from the headspace into the very surface of the liquid from the formation of tiny red eddies in the surface layer of the currently yellow solution.

\section{Step 5: Turbulent Mixing}

After observing the diffusion, vigorously shake the bottles to demonstrate turbulent mixing.

Depending on the level of students, instructors can ask what processes are controlling the movement of $\mathrm{CO}_{2}$ from the headspace to the water, with diffusion being the dominant gas exchange process before shaking and turbulent mixing. After shaking, the freshwater bottle will turn red, while the seawater bottle remains yellow (Figure 4). The reason for this is that at room temperature, $\mathrm{CO}_{2}$ solubility is not sufficient to overcome the buffering capacity of the seawater and reduce the $\mathrm{pH}$ below 4, the point where the indicator changes color; the freshwater bottle has little or no buffering capacity and thus the $\mathrm{pH}$ will immediately drop sufficiently to allow the indicator to change color. It is possible to return the freshwater to

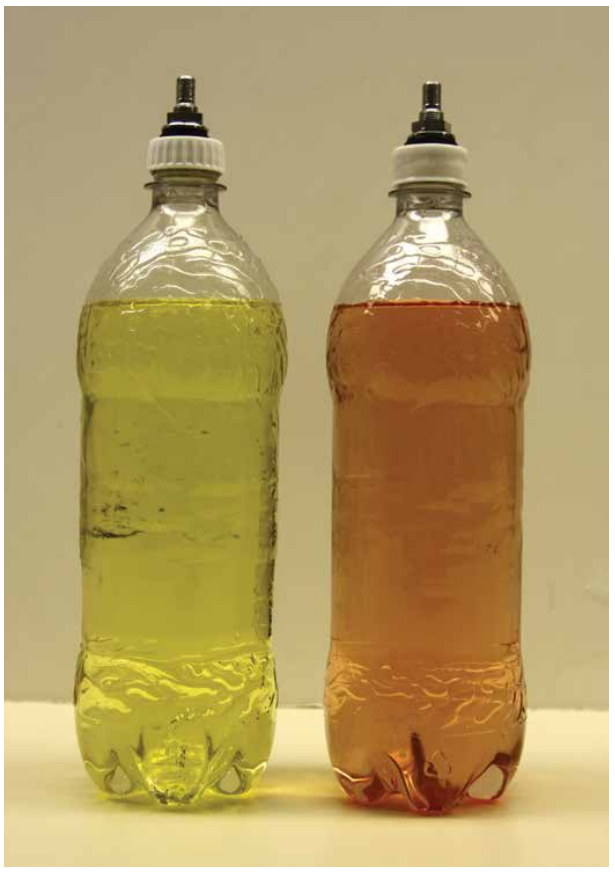

Figure 4.

Demonstration of buffering using methyl red indicator dye. The bottle on the left contains saltwater and the one on the right contains freshwater.

yellow by increasing the $\mathrm{pH}$. Remove all but about one-third of the water from the bottle (to increase gas exchange with the water). Then, squeeze the bottle three or four times to exchange the headspace air with room air. Replace the cap on the bottle and shake vigorously. The headspace air exchangeshake process will need to be repeated five or more times, but the water in the bottle will begin to return to a yellow color. Please refer to the supplemental online material for an example student laboratory worksheet.

\section{Hands-on Activity}

This laboratory exercise works best with groups of two to five students. The duration of the exercise depends largely on the detail of questions and calculations completed by students, but can range between 30 minutes and two hours. The online supplemental worksheet typically takes students two hours, as it includes numerous calculations.

Most familiar materials (e.g., sugar, salt) are more soluble in hot water than cold, but for gases like $\mathrm{CO}_{2}$, the reverse is true. This activity examines how water temperature affects gas solubility. The use of $\mathrm{pH}$ strips or a $\mathrm{pH}$ meter is optional. If measuring (not just calculating) $\mathrm{pH}$, have the students take a $\mathrm{pH}$ reading before the $\mathrm{CO}_{2}$ addition.

\section{Step 1: Prepare the Bottles}

Each group needs two bottles. Add 0.8 L of warm water (approximately $50^{\circ} \mathrm{C}$ ) to one bottle and $0.8 \mathrm{~L}$ of cold water (approximately $10^{\circ} \mathrm{C}$ ) to the other bottle. If measuring $\mathrm{pH}$, do so now.

\section{Step 2: Caps}

Loosely screw on the caps and squeeze the bottles to remove all air from the headspace. Then, tighten the caps. This step is important to best visualize the difference in $\mathrm{CO}_{2}$ uptake between the two bottles. Note: Depending on the audience, now is a great time to make a few assumptions and ask students questions (refer to the supplemental online material for a sample laboratory worksheet). For example, we assume only water is in the bottle (i.e., no $\mathrm{CO}_{2}$ has dissolved into the water) and ask students to calculate the $\mathrm{pH}$ (7.0) and number of moles of $\mathrm{CO}_{2}$ in the bottle (0 moles).

\section{Step 3: $\mathrm{CO}_{2}$ Addition}

Take the bottles to the instructor to be filled with 30 psi of $\mathrm{CO}_{2}$ from the gas tank. (The pressure of gas released into each bottle is controlled using the gas regulator.) Note: After 


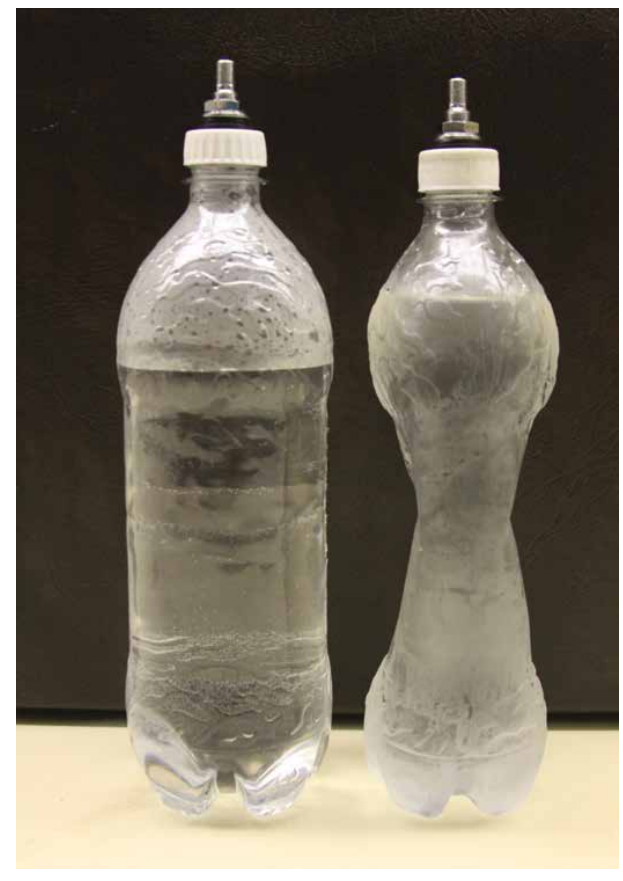

Figure 5. The bottle on the left contains warm water and the one on the right contains cold water. After removing all air from the headspace, the two bottles were filled with $\mathrm{CO}_{2}$ and then shaken. Notice the difference in pressure between the two bottles.

filling, all students in the group should touch the bottles, and notice their firmness.

\section{Step 4: Measure Pressure}

Students can measure the initial pressure in the bottles using a hand-held tire pressure gauge. Be aware that a good seal with the tire pressure gauge is necessary to avoid excessive loss of gas from the bottle, and the pressure should only be measured once, as this measurement process will cause some loss of gas from the bottle. At this point in the activity, it is possible to calculate the number of moles of $\mathrm{CO}_{2}$ in the bottles using the ideal gas law (see below for a detailed description).

\section{Step 5: Turbulent Mixing}

Shake the bottles vigorously, and notice the decrease in pressure in both bottles. The cold bottle actually collapses as the $\mathrm{CO}_{2}$ dissolves into the water, while the bottle with warm water becomes noticeably less pressurized (Figure 5). If using the $\mathrm{pH}$ strips, students can take the post- $\mathrm{CO}_{2}$ addition reading and reflect on why the calculated and actual $\mathrm{pH}$ varies (Table 2). (The actual change in $\mathrm{pH}$ will depend on the temperature and water used.) Note: By making a few assumptions, students can calculate the amount of $\mathrm{CO}_{2}$ taken up by each liquid and, therefore, the number of moles of $\mathrm{H}^{+}$released into each bottle and subsequent $\mathrm{pH}$. See supplemental online material for sample student questions.

To allow students to calculate the change in the $\mathrm{pH}$ of the water between the warm and cold bottles, we provide our students with a percent uptake of $\mathrm{CO}_{2}$ from the headspace for each bottle. More advanced students could also measure the change in bottle volume to approximate the quantity of $\mathrm{CO}_{2}$ dissolved into the water (Table 3). To measure bottle volume, begin by assuming the pressure in the headspace of the bottle after $\mathrm{CO}_{2}$ uptake is equal to atmospheric pressure. (Unfortunately, it is not possible to measure the pressure inside the bottles after shaking with the tire pressure gauges to obtain an exact pressure.) Then, determine the volume of the bottle by measuring the volume of water displaced when the bottle is submerged in water. Using the student-calculated volumes, or the values from Table 3 , students can calculate how much of the $\mathrm{CO}_{2}$ placed into the headspace of the warm and cold bottles dissolved into the water (see the theory section for full equations).

Calculating the actual change in ocean $\mathrm{pH}$ due to increased atmospheric $\mathrm{CO}_{2}$ concentrations is beyond the scope of this laboratory exercise. In order to easily quantify the process, numerous simplifying assumptions are required: the ocean is uniformly mixed, there is no $\mathrm{CO}_{2}$ uptake by biological organisms, and the ocean lacks any buffering capacity. Rather than

Table 2. Example table of measured $\mathrm{pH}$ before and after addition of $\mathrm{CO}_{2}$ to bottles containing $0.8 \mathrm{~L}$ of water at the University of Hawai'i, Manoa. Note that for the seawater compared to freshwater demonstration, if $0.8 \mathrm{~L}$ of water is used, rather than the approximately $1 \mathrm{~L}$ suggested in the Laboratory Worksheet posted online, the $\mathrm{pH}$ of the seawater bottle drops low enough to cause a change in water color. Remember the actual $\mathrm{pH}$ will vary depending on the source of the water, but it is clear that $\mathrm{pH}$ of the water drops significantly after $\mathrm{CO}_{2}$ is added.

$\mathrm{pH}$ Pre- $\mathrm{CO}_{2}$ Addition $\mathrm{pH}$ Post- $\mathrm{CO}_{2}$ Addition

\begin{tabular}{|lll|} 
Seawater & 8.0 & 5.6 \\
Freshwater & 8.1 & 5.5 \\
\hline Hot Water $\left(50^{\circ} \mathrm{C}\right)$ & 8.1 & 5.2 \\
\hline Cold Water $\left(12^{\circ} \mathrm{C}\right)$ & 8.1 & 5.0 \\
\hline
\end{tabular}

Table 3. Change in bottle volume with the hot and cold water additions. The decrease in bottle volume is caused by dissolution of gas from the headspace into the water, causing a decrease in headspace volume. (The initial volume of the bottle is $1,000 \mathrm{~cm}^{3}$, and after shaking the bottle with $10^{\circ} \mathrm{C}$ water, the volume of the bottle dropped to $900 \mathrm{~cm}^{3}$, decreasing the volume of the bottle by $100 \mathrm{~cm}^{3}$, which is a $50 \%$ change in the volume of the headspace.)

\begin{tabular}{|ccc|} 
& Change in Volume & Percent Change \\
\hline $10^{\circ} \mathrm{C}$ & $100 \mathrm{~cm}^{3}$ & $50 \%$ \\
$60^{\circ} \mathrm{C}$ & $20 \mathrm{~cm}^{3}$ & $10 \%$ \\
\hline
\end{tabular}


make these simplistic assumptions, we suggest challenging students to discuss whether or not the bottle exercise provides a good model of oceanic $\mathrm{CO}_{2}$ uptake and $\mathrm{pH}$ change. Current evidence indicates that surface ocean temperatures are increasing (Levitus et al., 2000), likely due to increased greenhouse gases in the atmosphere. From the lab exercise, students can actually see that less gas dissolves into the warm water than the cold water. An instructor-led discussion, or laboratory questions, can explore how increased atmospheric $\mathrm{CO}_{2}$ concentrations coupled with increased ocean surface temperatures affect the capacity of the ocean to take up excess atmospheric $\mathrm{CO}_{2}$. This laboratory exercise is a simplification of a very complex system, but it demonstrates that (1) increasing the concentration of $\mathrm{CO}_{2}$ in the atmosphere decreases the $\mathrm{pH}$ of the ocean, and (2) as ocean temperatures increase, gas uptake decreases.

Humans and $\mathrm{CO}_{2}$

In addition to understanding the effects of $\mathrm{CO}_{2}$ on ocean $\mathrm{pH}$, this lab provides an opportunity for students to consider how human activities are contributing to increased atmospheric $\mathrm{CO}_{2}$ concentrations. There are numerous Web-based activities for students to determine their carbon footprint, but we decided to have our students make actual pen and paper calculations that could then be tied back to how humans are increasing atmospheric $\mathrm{CO}_{2}$ concentrations, which in turn affect the ocean.

\section{DOES WATER TEMPERATURE INFLUENCE THE QUANTITY OF $\mathrm{CO}_{2}$ THE WATER IS ABLE TO TAKE UP?}

To begin the humans and $\mathrm{CO}_{2}$ section, we ask students to list different ways they create $\mathrm{CO}_{2}$. Answers vary from using cars and electricity to breathing. The students are then led through a series of exercises to put into perspective how much $\mathrm{CO}_{2}$ different processes release. For example, a human respires approximately $1 \mathrm{~kg}$ of $\mathrm{CO}_{2}$ each day, which is equivalent to 22.7 moles of $\mathrm{CO}_{2}$ per day. Students can also examine the influence of fossil fuels on atmospheric $\mathrm{CO}_{2}$. If we assume the combustion of one gallon $(3.8 \mathrm{~L})$ of gasoline releases $8.8 \mathrm{~kg}$ of $\mathrm{CO}_{2}$ (see http://www.epa.gov/otaq/climate/420f05002.htm), students can evaluate the amount of $\mathrm{CO}_{2}$ released by cars with different fuel efficiencies. In the supplemental worksheet, we compare three types of cars and calculate how much $\mathrm{CO}_{2}$ each car releases if it is driven 10 miles $(16 \mathrm{~km})$ a day over the course of a year. Depending on the age of students, it may be more beneficial for students to calculate how much $\mathrm{CO}_{2}$ their cars generate driving to and from school. To examine this problem at a larger scale, knowing the United States consumes $18,810,000$ barrels of oil each day, students can calculate how many moles of $\mathrm{CO}_{2}$ are released into the atmosphere in one day and in one year.

Another activity involves determining the significance of electricity consumption on $\mathrm{CO}_{2}$ emissions. Using EPA data on electricity generation and power sources, it is possible to calculate the amount of $\mathrm{CO}_{2}$ released to the atmosphere using light bulbs and electric appliances. For example, in Hawai'i, oil is the major source of electricity, and $\mathrm{CO}_{2}$ is produced at a rate of $0.609 \mathrm{~kg} \mathrm{CO}_{2} / \mathrm{kWh}$ (EPA eGRID at http://www.epa.gov/ cleanenergy/documents/egridzips/eGRID2010V1_1_year07_ SummaryTables.pdf). By knowing the number and wattage of light bulbs in the classroom, students are asked to calculate how much $\mathrm{CO}_{2}$ is released to power the lights for the length of our class. This exercise can also be extrapolated to calculate the amount of $\mathrm{CO}_{2}$ released for numerous electronic devices.

These are only a few activities that instructors can include to allow students to better understand how much $\mathrm{CO}_{2}$ is released during different human activities. There are numerous free online carbon footprint calculators that students can use, including one from The Nature Conservancy (http://www. nature.org/greenliving/carboncalculator), to calculate how many tons of $\mathrm{CO}_{2}$ equivalents per year they generate.

It is also possible to convert the amount of carbon located in the different reservoirs on Earth from Pg C to equivalent $\mathrm{CO}_{2}$. This conversion would allow direct comparison between reservoirs and the calculations made above, such as the amount of $\mathrm{CO}_{2}$ released by the combustion of oil.

$1 \mathrm{Pg} \mathrm{C}=1 \mathrm{Gt} \mathrm{C}=10^{9}$ tons $\mathrm{C}$

1 ton $\mathrm{C}=3.67$ tons $\mathrm{CO}_{2}$ equivalent

For example, the following equation can be used to convert the amount of carbon in the oceanic reservoir, 4,000 Pg C, to tons $\mathrm{CO}_{2}$ equivalent.

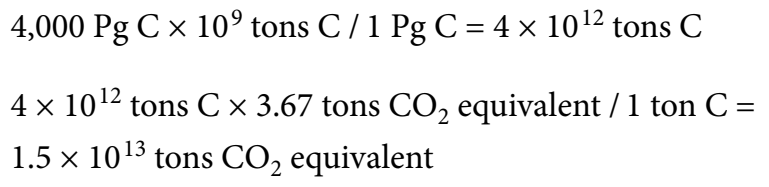


THEORY

Henry's Law

Henry's Law states that at constant temperature the amount of gas in solution is proportional to the partial pressure of the gas in equilibrium with the liquid (i.e., in the headspace above itin the case of our demonstration, the partial pressure of the gas in the headspace is equal to the measured pressure, as we have expelled all the other gases before adding the $\mathrm{CO}_{2}$.) Increasing the headspace pressure of a gas increases the solubility of the gas, while increasing the temperature of the solution decreases the solubility of the gas.

This lab activity demonstrates the temperature aspect of Henry's Law: a decrease in the water temperature increases the solubility of the $\mathrm{CO}_{2}$ in solution. It would also be possible to demonstrate the pressure aspect by using constant temperature water and altering the pressure of the gas injected into the headspace. The hands-on laboratory activity is a simplified version of ocean-atmosphere interactions that highlights how varying temperatures, not pressures, affect $\mathrm{CO}_{2}$ solubility in water.

\section{Ideal Gas Law}

The ideal gas law (Equation 5) can be used to calculate the number of moles of $\mathrm{CO}_{2}$ in the headspace, where $\mathrm{P}=$ pressure $(\mathrm{kPa}), \mathrm{V}=$ volume $(\mathrm{L}), \mathrm{n}=$ moles, $\mathrm{R}=$ the gas constant $=8.431 \mathrm{~J} \mathrm{moles}^{-1} \mathrm{~K}^{-1}$, and $\mathrm{T}=$ temperature $(\mathrm{K})$.

$\mathrm{P} \times \mathrm{V}=\mathrm{n} \times \mathrm{R} \times \mathrm{T}$

By knowing the volume of the headspace in the $1 \mathrm{~L}$ bottle, the room temperature, and the atmospheric pressure, the moles of gas in the headspace of the bottle can be calculated. At 1 atmosphere (101.3 kPa or $14.7 \mathrm{psi})$ and $25^{\circ} \mathrm{C}, 1$ mole of gas has a volume of $23.9 \mathrm{~L}$. (The volume of an ideal gas at standard temperature and pressure, or STP $\left[0^{\circ} \mathrm{C}\right]$, is $22.4 \mathrm{~L}$.) Equation 6 shows how to calculate the moles of gas in the headspace of the $1 \mathrm{~L}$ bottle containing $0.8 \mathrm{~L}$ of water at room pressure (6a) and after the bottle is filled with $30 \mathrm{psi}$ of $\mathrm{CO}_{2}(6 \mathrm{~b})$.

$$
\frac{(101.3 \mathrm{kPa}) \times(0.2 \mathrm{~L})}{(298 \mathrm{~K}) \times\left(8.431 \mathrm{~J} \mathrm{moles}^{-1} \mathrm{~K}^{-1}\right)}=0.008 \text { moles gas }
$$

$$
\frac{(206.7 \mathrm{kPa}) \times(0.2 \mathrm{~L})}{(298 \mathrm{~K}) \times\left(8.431 \mathrm{~J} \mathrm{moles}^{-1} \mathrm{~K}^{-1}\right)}=0.016 \text { moles gas }
$$

After the addition of $\mathrm{CO}_{2}$ to the headspace of the bottle using the gas cylinder, the pressure in the bottle is approximately doubled (room pressure is $14.7 \mathrm{psi}$, and we increase it to approximately $30 \mathrm{psi}$ ). Therefore, the number of moles of gas in the headspace is also doubled.
$\mathrm{pH}$

The $\mathrm{pH}$ of a solution is a measure of the concentrations of protons $\left(\left[\mathrm{H}^{+}\right]\right)$available. The larger the quantity of $\mathrm{H}^{+}$present in the solution, the lower the $\mathrm{pH}$ of the solution. Mathematically, $\mathrm{pH}$ is calculated using Equation 7.

$\mathrm{pH}=-\log \left(\left[\mathrm{H}^{+}\right]\right)$

Therefore, in pure water at $25^{\circ} \mathrm{C}$, where $\left[\mathrm{H}^{+}\right]=1.0 \times 10^{-7} \mathrm{M}$ $(\mathrm{M}=$ molarity $=$ moles per liter $)$, the $\mathrm{pH}$ of the solution is 7.0.

In the lab activity, students first calculate the number of moles of gas in the headspace of each bottle (Equation 6a,b). By filling the headspace of the bottle with $30 \mathrm{psi}$ of pure $\mathrm{CO}_{2}$ gas, the pressure of gas in the headspace is doubled, thus doubling the quantity of gas in the headspace (Equation 8).

0.008 moles of gas in headspace at $15 \mathrm{psi} \times 2=$ 0.016 moles of gas

Knowing the headspace was filled with pure $\mathrm{CO}_{2}$ gas, there are 0.016 moles of $\mathrm{CO}_{2}$ in the headspace of the bottle.

Students then calculate the $\mathrm{pH}$ of the $0.8 \mathrm{~L}$ of water in the bottle (Equation 9). For simplicity, we ask students to assume that all of the $\mathrm{CO}_{2}$ added into the bottle by the $\mathrm{CO}_{2}$ cylinder dissolves from the headspace into the water. We further assume that all of the $\mathrm{CO}_{2}$ that dissolved into the water became $\mathrm{HCO}_{3}^{-}$, and therefore 0.016 moles of $\mathrm{H}^{+}$are released into $0.8 \mathrm{~L}$ of water. Using Equation 9, the molarity of $\mathrm{H}^{+}$released can be calculated.

0.016 moles $\mathrm{H}^{+} / 0.8 \mathrm{~L}=0.02 \mathrm{M} \mathrm{H}^{+}$

The total concentration of $\mathrm{H}^{+}$in the bottle is then calculated by adding $0.02 \mathrm{M} \mathrm{H}^{+}$from the dissolution of $\mathrm{CO}_{2}$ (Equation 9) to the concentration of $\mathrm{H}^{+}$present from the water, $\left[\mathrm{H}^{+}\right]=$ $1.0 \times 10^{-7}+0.02=0.02$. Using Equation 7 to calculate $\mathrm{pH}$ : $\log (0.02)=1.7$. (Note the addition of the $\left[\mathrm{H}^{+}\right]$from the water does not change the $\mathrm{pH}$ of the water in this example due to the large $\left[\mathrm{H}^{+}\right]$from the dissociation of $\mathrm{H}_{2} \mathrm{CO}_{3}$.)

The $\mathrm{pH}$ of water in the bottle is not actually 1.7 because all of the dissolved $\mathrm{CO}_{2}$ does not dissociate into $\mathrm{HCO}_{3}^{-}$and $\mathrm{H}^{+}$in the water. As mentioned previously, the majority of $\mathrm{CO}_{2}$ gas dissolving in water becomes $\mathrm{CO}_{2(\mathrm{aq})}$, with only 1 in 400 actually becoming $\mathrm{HCO}_{3}^{-}$and releasing a proton in the process. Therefore, to accurately calculate the $\mathrm{pH}$ in our exercise, it is necessary to divide our calculated $\left[\mathrm{H}^{+}\right]$by 400 . If all the $\mathrm{CO}_{2}$ from the headspace dissolved into the water, the $\mathrm{pH}$ of the solution is calculated using Equations 10 through 12.

0.016 moles $\mathrm{CO}_{2(\mathrm{~g})}$ in headspace $\longrightarrow 0.016$ moles $\mathrm{CO}_{2(\mathrm{aq})}$ 
0.16 moles $\mathrm{CO}_{2(\mathrm{aq})} \times \frac{1 \text { mole } \mathrm{H}_{2} \mathrm{CO}_{3}}{400 \text { moles } \mathrm{CO}_{2(\mathrm{aq})}} \times \frac{1 \text { mole } \mathrm{HCO}_{3}}{1 \text { mole }_{2} \mathrm{CO}_{3}} \times$

$\frac{1 \text { mole }^{+}}{1{\text { mole } \mathrm{HCO}_{3}}^{+}}=4 \times 10^{-5}$ moles $\mathrm{H}^{+}$

$\mathrm{pH}=-\log \left(4 \times 10^{-5}\right.$ moles $\left.\mathrm{H}^{+} / 0.8 \mathrm{~L}\right)=4.3$

From the actual lab activity, the change in $\mathrm{pH}$ for the different water temperatures can be calculated using the percent change in volume given in Table 3 (Equations 13 and 14).

$4 \times 10^{-5}$ moles $\mathrm{H}^{+} \times 10 \%\left(\right.$ at $\left.50^{\circ} \mathrm{C}\right)=4 \times 10^{-6}$ moles $\mathrm{H}^{+}$,

$\mathrm{pH}=5.3$

$4 \times 10^{-5}$ moles $\mathrm{H}^{+} \times 50 \%\left(\right.$ at $\left.10^{\circ} \mathrm{C}\right)=2 \times 10^{-5}{\text { moles } \mathrm{H}^{+},}$

$\mathrm{pH}=4.6$
USEFUL WEB RESOURCES

» http://www.epa.gov/climatechange/fq/emissions.html

» http://cdiac.ornl.gov/pns/faq.html

» http://www.oceanacidification.noaa.gov

\section{REFERENCES}

Levitus, S., J. Antonov, T. Boyer, and C. Stephens. 2000. Warming of the world ocean. Science 287:2,225-2,229, http://dx.doi.org/10.1126/ science.287.5461.2225.

Libes, S. 2009. Introduction to Marine Biogeochemistry, $2^{\text {nd }}$ ed. Elsevier, Burlington, $928 \mathrm{pp}$.

Open University Team, eds. 1989. Seawater: Its Composition, Properties and Behavior. 130 pp.

Petit, J.R., J. Jouzel, D. Raynaud, N.I. Barkov, J.-M. Barnola, I. Basile, M. Bender, J. Chappellaz, M. Davis, G. Delaygue, and others. 1999. Climate and atmospheric history of the past 420,000 years from the Vostok ice core, Antarctica. Nature 399:429-436, http://dx.doi.org/10.1038/20859.

Wigley, T.M.L. 1983. The pre-industrial carbon dioxide level. Climatic Change 5(4):315-320, http://dx.doi.org/10.1007/BF02423528.

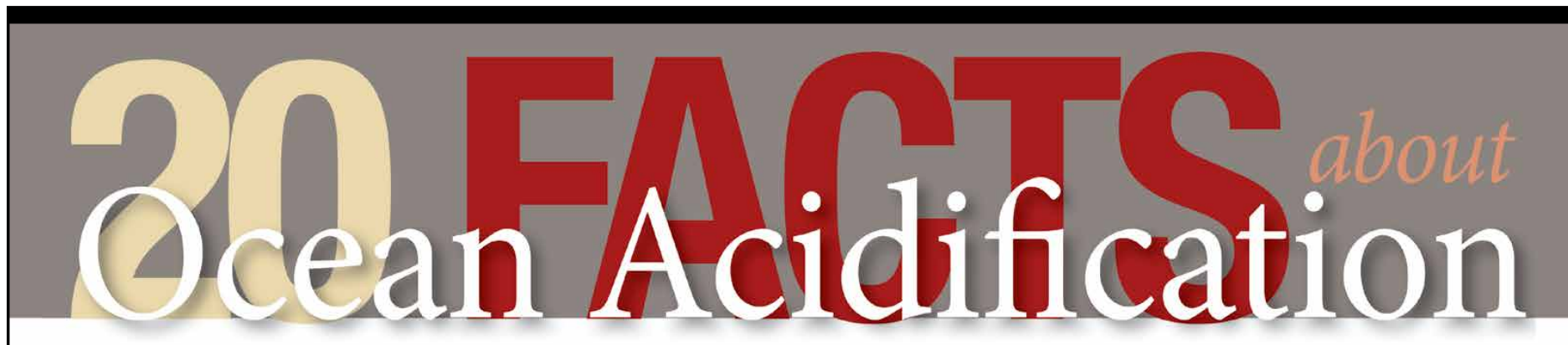

http://www.whoi.edu/OCB-OA/FAQs

\section{Factsheet Available Now}

Highlights from the popular "Frequently Asked Questions about Ocean Acidification" document have been collected in a new document, "20 Facts about Ocean Acidification." The factsheet can be downloaded from the Ocean Acidification FAQ homepage, at http://www.whoi.edu/ OCB-OA/FAQs. It is presently available in English; French, German, and Spanish editions will be available shortly. Italian, Greek, and Arabic versions are planned for later in 2014. 